\title{
IMPACT OF RENEWED CATTLE GRAZING ON FLORISTIC COMPOSITION IN THE HRUBÝ JESENÍK MOUNTAINS
}

\author{
Marie Mrázková-Štýbnarová1, Josef Holec², Radek Štencl ${ }^{3}$, Michaela Kolářová2, \\ Luděk Tyšer ${ }^{2}$, Oldřich Látal ${ }^{1}$
}

\footnotetext{
${ }^{1}$ Agrovýzkum Rapotín s.r.o., Výzkumníků 267, 78813 Vikýřovice, Czech Republic

${ }^{2}$ Czech University of Life Sciences Prague, Kamýcká 129, 16500 Praha 6 - Suchdol, Czech Republic

${ }^{3}$ Protected Landscape Area Administration Jeseníky, Šumperská 93, 79001 Jeseník, Czech Republic
}

Link to this article: https://doi.org/10.11118/actaun202068020335

Received: 15. 1. 2020, Accepted: 27. 3. 2020

To cite this article: MRÁZKOVÁ-ŠTÝBNAROVÁ MARIE, HOLEC JOSEF, ŠTENCL RADEK, KOLÁŘOVÁ MICHAELA, TYŠER LUDĚK, LÁTAL OLDŘICH. 2020. Impact of Renewed Cattle Grazing on Floristic Composition in the Hrubý Jeseník Mountains. Acta Universitatis Agriculturae et Silviculturae Mendelianae Brunensis, 68(2): 335-342.

\begin{abstract}
The aim of the study was to estimate changes in the floristic composition near Švýcárna lodge (1304 m a.s.l.), where cattle grazing after a long-term management cessation was introduced on a pasture area of 3.6 ha in 2012. The pasture was divided into two grazing sub-localities: P1 (Nar) with dominance of Nardus stricta and Avenella flexuosa and P2 (Des) with dominance of Deschampsia cespitosa. For grazing, Highland Cattle was used with a stocking rate up to 1 livestock unit per ha and year. The floristic composition was evaluated and statistically analyzed. After six years of restored grazing the overall species richness enhanced and a higher dominance of rare and endangered species was found. The dominance of some common species like Vaccinium myrtillus, and Calamagrostis villosa tended to decrease within a grazing period in favor of new species colonisation.
\end{abstract}

Keywords: suckler cows, renewed grazing, species diversity, nature conservation

\section{INTRODUCTION}

Biodiversity of Central European seminatural upland grasslands is steadily declining, due to either abandonment or management intensification (Merunková and Chytrý, 2012). Especially, the biodiversity of species-rich seminatural meadows is declining across Europe due to ceased management (Hellström et al., 2003). The continuation of traditional ways of grassland management that would best preserve biodiversity is often not compatible with the requirements of an intensive livestock production. Therefore, grassland is at risk of being abandoned from an agricultural use (Isselstein et al., 2005). The impacts of a land abandonment and subsequent woody colonization on vegetation composition and plant traits were studied e.g. by Prévosto et al. (2011), whose study showed a set of similarities in responses of the vegetation in plant traits after land abandonment.

Grazing is considered as a suitable tool to maintain biodiversity of grasslands as documented by Metera et al. (2010). The same was proven also for the territory of the Czech Republic (Veselý, 2000; Žáková et al., 2004; Hejcman et al., 2006; Hofhanzlová, 2006; Mládek et al., 2006; Pavlů et al., 2007; Mládek, 2008; Brabec et al., 2011). Due to the above-mentioned facts, grazing is renewed in the Czech Republic in the protected areas where it was probably pursued in the past (e.g. the White Carpathians Mountains (Mts.), the Giant Mts., the Beskydy Mts.). 
In 2012, grazing was restored also in the Hrubý Jeseník Mts. (the Praděd National Natural Reserve) in the Švýcárna lodge surroundings (Štencl, 2012; Bureš, 2013). The main aim of the cattle grazing reintroduction was the reinforcement of nonproduction functions of alpine grasslands (floristic diversity, landscape forming, attractiveness for the tourism etc.). Also, the production function of alpine grassland must not be ignored, which is closely connected with the proper cattle nutrition, and thus, with the animals' health and their condition.

The aim of the study was to estimate changes in the floristic composition in the locality of Švýcárna lodge (1 $304 \mathrm{~m}$ a.s.l., the Praděd National Natural Reserve), where cattle grazing was introduced after a long-term management cessation in 2012.

\section{MATERIALS AND METHODS}

\section{Study Site}

Our research was conducted in the mountain area near the Švýcárna lodge situated in the Hrubý Jeseník Mts. (the Praděd National Natural Reserve; $1304 \mathrm{~m}$ a.s.l.). In Praděd (1 $491 \mathrm{~m}$ a.s.l), around $2.5 \mathrm{~km}$ distant from the Švýcárna lodge) there is an average annual temperature of $0.9^{\circ} \mathrm{C}$ and annual precipitation of $1231 \mathrm{~mm}$. The experimental area is in the ownership of the Czech Republic with the right to manage for the Forests of the Czech Republic, a state-owned enterprise. The grazed area is categorized as an open country according to the present Forest Management Plan. Based on the declaration of The Regional Authority of the Olomouc Region (about the temporary revocation of the land devoted to fulfil the forest services), the agricultural use of suckler cows (the Highland breed) for grazing was reestablished in 2012.

The rotational grazing system (three grazing cycles per year) was conducted on the site, which was divided by the road into two grazing sublocalities differing in dominant grass species. The sub-locality P1 (Nar) with a dominance of Nardus stricta L. and Avenella flexuosa (L.) Drejer was situated above the lodge while the sublocality P2 (Des) with a dominance of Deschampsia cespitosa (L.) P. Beauv. was situated below the lodge. The whole plot area was 3.6 ha. The stocking rate was up to 1 livestock unit per ha and year.

The amount of soil nutrients available to plants during the growing season was estimated in a Mehlich III solution in 2013. On average, an extremely acid soil reaction ( $\mathrm{pH}=3.7$ ) was found and simultaneously a low content of calcium (232.8 mg.kg ${ }^{-1}$ ), phosphorus (10.0 mg. $\mathrm{kg}^{-1}$ ) and magnesium (69.8 $\mathrm{mg}^{\mathrm{kg}} \mathrm{kg}^{-1}$ ) in the soil.

The vegetation in the lodge surroundings was characterized as mosaic of close alpine grasslands, the subalpine Vaccinium vegetation, the subalpine tall grasslands and the subalpine tall-forb vegetation (Chytrý et al., 2010), with the dominant species Nardus stricta L., Deschampsia cespitosa (L.) P. Beauv., Avenella flexuosa (L.) Drejer, Bistorta officinalis Delarbre, Calamagrostis villosa (Chaix) Gmel., Festuca supina Schur and Luzula sylvatica (Huds.) Gaudin.

\section{Evaluated Parameters}

Five permanent plots (one plot area: $5 \mathrm{~m} \times 5 \mathrm{~m}$ ) were established in 2012 at different sites of the grazed area (two in the sub-locality P1: P1-A, P1-B; and three in the sub-locality P2: P2-A, P2-B, P2-C) to monitor changes in floristic composition.

The floristic composition was determined each year at the beginning of July. We evaluated phytosociological relevés (Moravec et al., 1994) at permanent plots, whereas the projective dominance of particular species was estimated visually in \%. The nomenclature of vascular plants followed Danihelka et al. (2012). The vascular plant species were classified into five groups according to their threat status (Grulich, 2017).

\section{Statistical Analyses}

The numbers of species for each plot were plotted and their dependence on the year was calculated by means of a linear regression model in the Statistica program (version 13.2). The species dominance in different experimental plots and their shift within time was analyzed using the multivariate analysis in the CANOCO 4.5 software (ter Braak and Šmilauer, 2002). Both sub-localities P1 and P2 were analyzed separately due to a substantial difference in a floristic composition between them. First, we used a detrended correspondence analysis (DCA), with detrending by segments. Due to rather short gradients on the first canonical axis (1.423 SD units for P1 and 2.517 SD units for P2) in the compositional turnover, a principal component analysis (PCA) was used to assess the overall variation patterns in the data set. Scaling was focused on inter-species distances and data were centered and standardized by species. For better interpretation, the explanatory variables (year and plots) were passively projected onto an ordination diagram.

\section{RESULTS}

Fig. 1 shows the results of changes in the plant species diversity of the experimental plots during 2012-2017. A number of 67 plant species in total was found in the experimental area within 6 years. On all experimental plots, an increase in the species richness was found within the study period (Fig. 1). The most remarkable increase and the highest number of species were recorded on plots with high soil moisture (P2-B and P2-C), probably as a consequence of mechanical soil disturbance caused by cattle movement and thus creation of small open habitats free of vegetation and the possibility of an establishment of new species. Soil moisture, however, was evaluated only visually. 


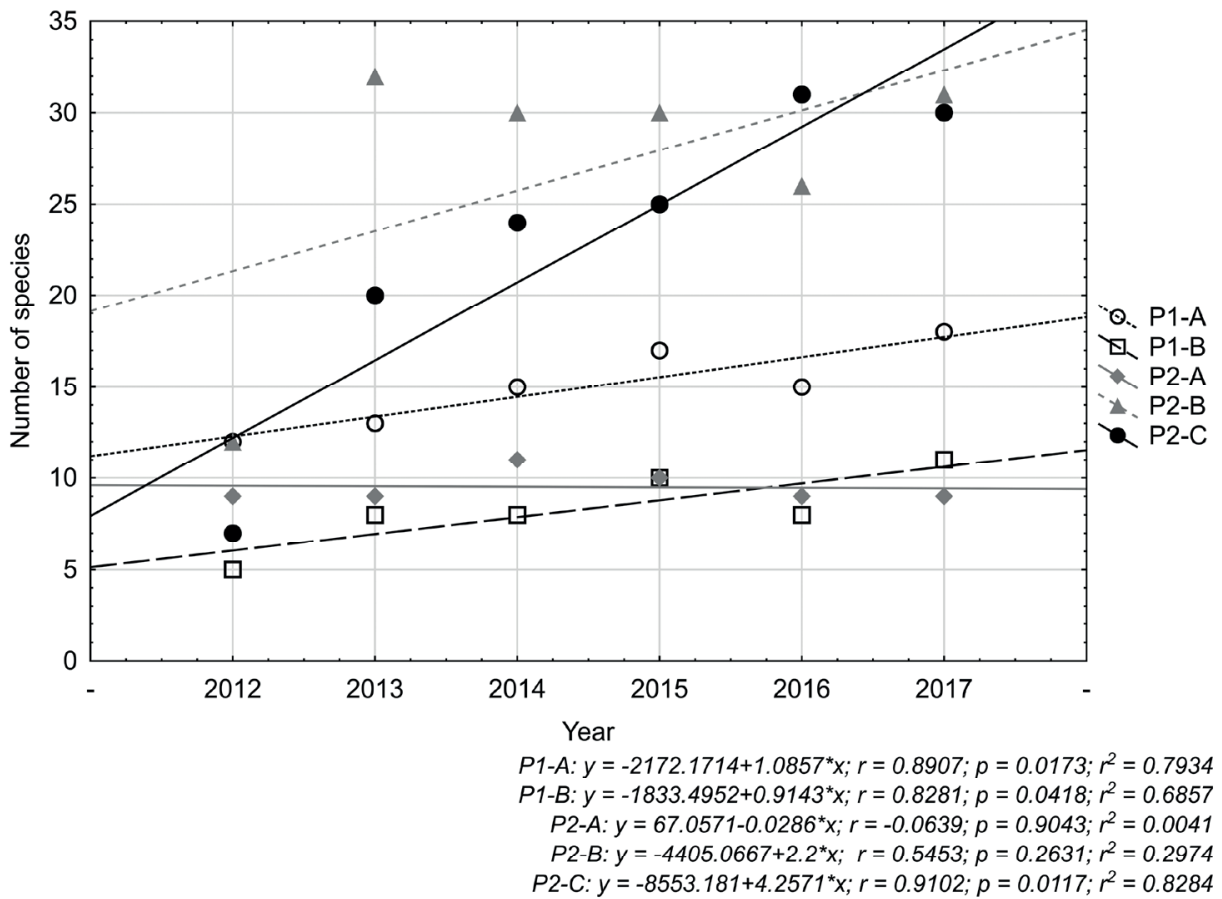

1: Scatterplot and linear regression of the species number in different plots versus the experimental year; regression equations, regression coefficients $\left(R^{2}\right)$ and correlation coefficients $(r)$ Legend: P1-A, P1-B, P2-A, P2-B, P2-C ... permanent plots $5 \mathrm{~m} \times 5 \mathrm{~m}$

I: IUCN category of endangerment of recorded species present in the Red List of Vascular Plants of the Czech Republic (CR - Critically Endangered, EN - Endangered, VUVulnerable, NT - Near Threatened, LC - Least Concern)

\begin{tabular}{ll}
\hline \multicolumn{1}{c}{ Species } & $\begin{array}{c}\text { IUCN } \\
\text { category }\end{array}$ \\
\hline Crepis mollis subsp. mollis (Jacq.) Asch. & CR \\
Carex bigelowii subsp. dacica (Heuff.) T. V. Egorova & EN \\
Hieracium stygium R. Uechtr. & EN \\
Cerastium fontanum Baumg. & VU \\
Festuca supina Schur & VU \\
Allium schoenoprasum subsp. schoenoprasum L. & NT \\
Crepis mollis subsp. succisifolia (All.) Dostál & NT \\
Epilobium palustre L. & NT \\
Ligusticum mutellina (L.) Crantz & NT \\
Phleum alpinum L. & NT \\
Potentilla aurea L. & NT \\
Luzula sudetica (Willd.) Schult. & LC \\
Tephroseris crispa (Jacq.) Rchb. & LC \\
Trientalis europaea L. & LC \\
Viola biflora L. & LC \\
\hline
\end{tabular}

Out of the total number of plant species found, 15 are present in the Red List of Vascular Plants of the Czech Republic (Grulich, 2017): 1 critically endangered, 2 endangered, 2 vulnerable, 6 near threatened, and 4 least concern (Tab. I). On most of the plots, an increase in the number of rare and endangered species was noticed during 2012-2017. As for the plot P1-A, the following plant species occurred newly in the vegetation during the years of monitoring: Hieracium stygium R. Uechtr., Ligusticum mutellina (L.) Crantz, Luzula sudetica (Willd.) Schult., Potentilla aurea L. and Trientalis europaea L. In the plot P1-B Trientalis europaea L. was recorded as a new species in 2014 comparing with the year 2012. The plot P2-A was characterized by the following new species occurrences: Ligusticum mutellina (L.) Crantz and Trientalis europaea L. Concerning the plot P2-B the following species were newly found: Crepis mollis subsp. succisifolia (All.) Dostál and Phleum alpinum L. In the plot P2-C the following plant species occurred newly in the vegetation: Epilobium palustre L., Luzula sudetica (Willd.) Schult, Tephroseris crispa (Jacq.) Rchb. and Viola biflora L.

Regarding the changes in the dominance of particular plant species, the results are shown in Fig. 2 (sub-locality P1) and Fig. 3 (sub-locality P2). In the PCA for the P1 sub-locality (Fig. 2), the first ordination axis explained $62.7 \%$ of the total variation and could be associated with different experimental plots. The second most important gradient in data variation (28.1\% of data variability) corresponds more to changes within time. P1-A and P1-B plots were characterized by a higher 


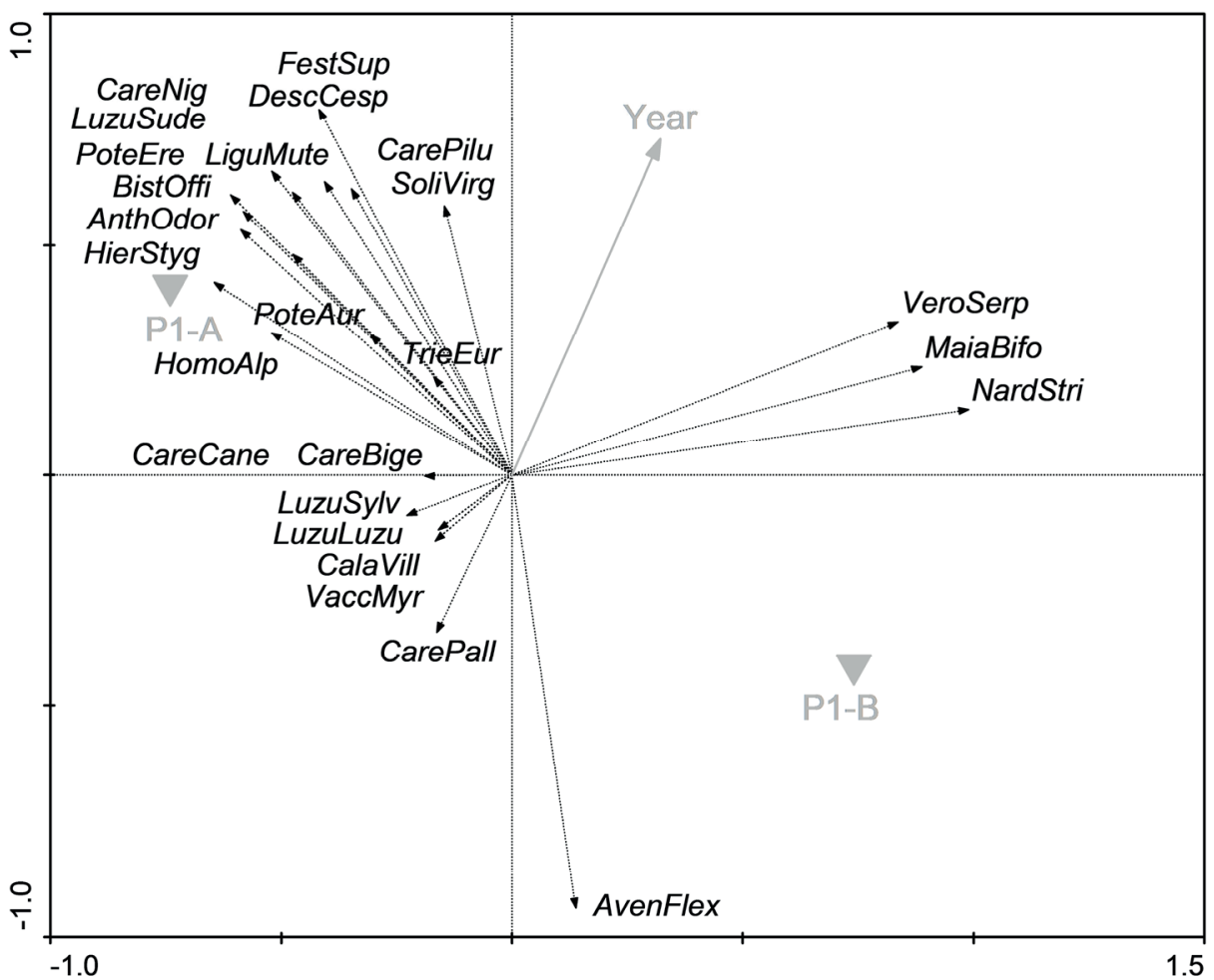

2: Sub-locality P1 - ordination diagram of principal component analysis (PCA) with passively projected year and experimental plots as supplementary variables

AnthOdor - Anthoxanthum odoratum L., AvenFlex - Avenella flexuosa (L.) Drejer, BistOffi Bistorta officinalis Delarbre, CalaVill - Calamagrostis villosa (Chaix) J. F. Gmel., CareBige - Carex bigelowii Torr. ex. Schwein subsp. dacica (Heuff.) T. V. Egorova, CareCane - Carex canescens L., CareNig - Carex nigra (L.) Reichard, CarePall - Carex pallescens L., CarePilu-Carex pilulifera L., DescCesp - Deschampsia cespitosa (L.) P. Beauv., FestSup - Festuca supina Schur, HierStyg Hieracium stygium R. Uechtr., HomoAlp - Homogyne alpina (L.) Cass., LiguMute - Ligusticum mutellina (L.) Crantz, LuzuLuzu - Luzula luzuloides (Lam.) Dandy et Wilmott, LuzuSude - Luzula sudetica (Willd.) Schult., LuzuSylv - Luzula sylvatica (Huds.) Gaudin, MaiaBifo Maianthemum bifolium (L.) F. W. Schmidt, NardStric - Nardus stricta L., PoteAur - Potentilla aurea L., PoteEre - Potentilla erecta (L.) Raeusch., SoliVirg - Solidago virgaurea L. subsp. minuta (L.) Arcang., TrieEur - Trientalis europaea L., VaccMyr - Vaccinium myrtillus L., VeroSerp - Veronica serpyllifolia L.

dominance of Avenella flexuosa (L.) Drejer which slightly decreased within experimental years. This decrease was also noticed for Vaccinium myrtillus L. and Calamagrostis villosa (Chaix) Gmel. On the contrary, the dominance of the species Festuca supina Schur slightly increased during six years of our monitoring. On the plot P1-B, the dominance of Nardus stricta L. significantly increased and gained dominance instead of Avenella flexuosa (L.) Drejer.

The first ordination axis in PCA for the P2 sub-locality (Fig. 3) explained $57.1 \%$ of the total variability and is associated with the year. The different experimental plots correlated more with the second ordination axis (24.2\% of data variation). On the plot P2-A, Avenella flexuosa (L.) Drejer was a dominating species which significantly decreased within the study period. The dominance of Deschampsia caespitosa (L.) P. Beauv. substantially increased. An increase in the dominance was noticed also for Anthoxanthum odoratum $\mathrm{L}$.
The dominance of Calamagrostis villosa (Chaix) Gmel. significantly decreased, a slight decrease was noticed also for Festuca supina Schur, Luzula sylvatica (Huds.) Gaudin and Bistorta officinalis Delarbre. On plots $\mathrm{P} 2-\mathrm{B}$ and $\mathrm{P} 2-\mathrm{C}$, the dominating species was Deschampsia cespitosa (L.) P. Beauv. On both plots we recorded a significant decrease of the dominance of Chaerophyllum hirsutum L. On the plot P2-B, the dominance of species Stellaria nemorum L. slightly decreased. On the plot P2-C, the dominance of Ranunculus repens L. increased.

\section{DISCUSSION}

Based on many floristic data from the end of $18^{\text {th }}$ century and from the $19^{\text {th }}$ century (Kolenati, 1860) up to the beginning of the $20^{\text {th }}$ century it is obvious, that forestless areas in Hrubý Jeseník Mts. were more diverse regarding their species and biotope diversity in times when they were 


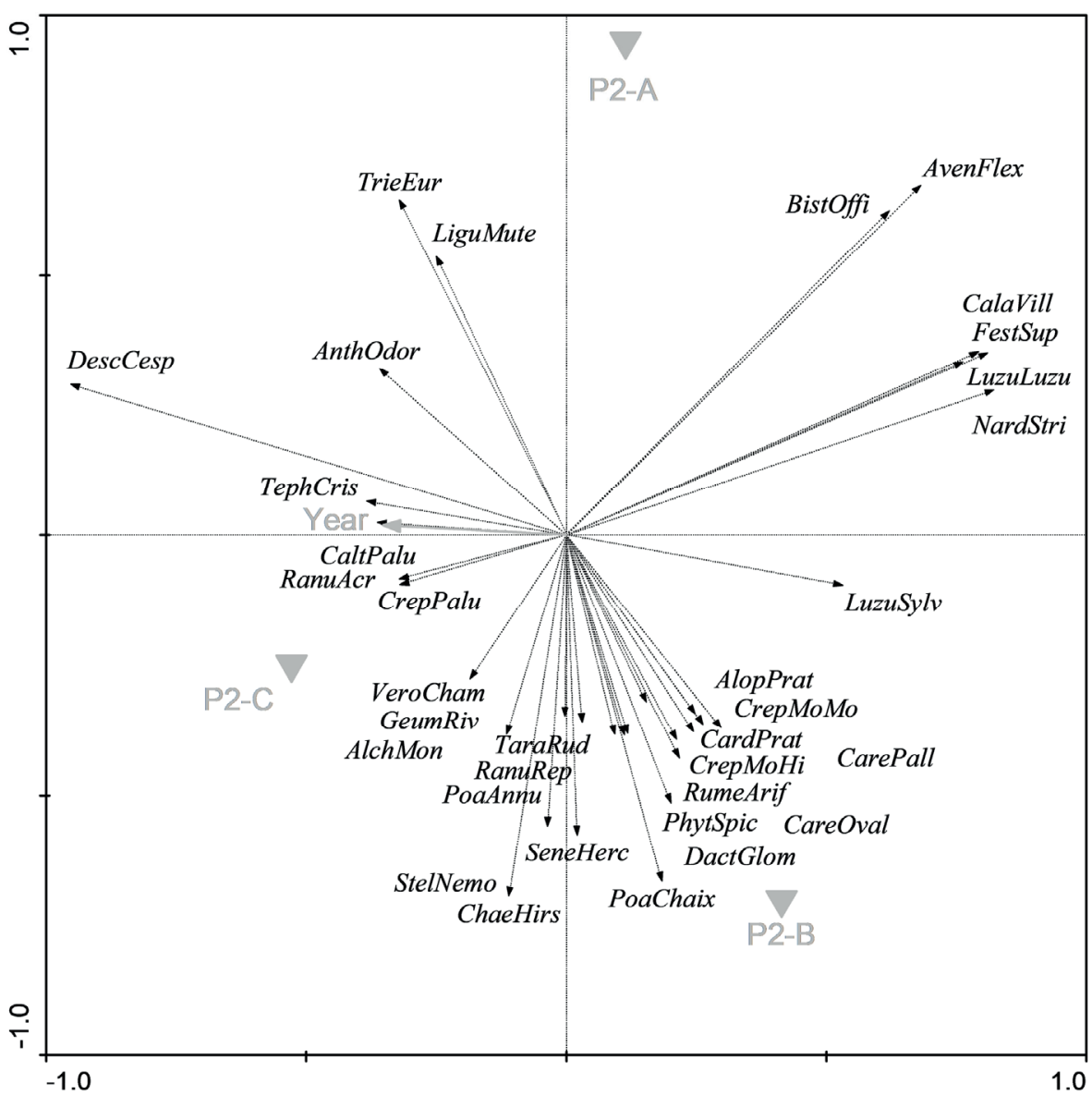

3: Sub-locality P2 - ordination diagram of principal component analysis (PCA) with passively projected year and experimental plots as supplementary variables (minimum species fit 11\% 34 out of 58 species)

AlchMon - Alchemilla monticola Opiz, AlopPrat - Alopecurus pratensis L., AnthOdor Anthoxanthum odoratum L., AvenFlex - Avenella flexuosa (L.) Drejer, BistOffi - Bistorta officinalis Delarbre, CalaVill - Calamagrostis villosa (Chaix) J. F. Gmel., CaltPalu - Caltha palustris L., CardPrat - Cardamine pratensis L., CareOval - Carex leporina L., CarePall - Carex pallescens L., ChaeHirs - Chaerophyllum hirsutum L., CrepMoHi - Crepis mollis (Jacq.) Asch. subsp. succisifolia (All.) Dostál, CrepMoMo - Crepis mollis (Jacq.) Asch. subsp. mollis, CrepPalu - Crepis paludosa (L.) Moench., DactGlom - Dactylis glomerata L., DescCesp - Deschampsia cespitosa (L.) P. Beauv., FestSup - Festuca supina Schur, GeumRiv - Geum rivale L., LiguMute - Ligusticum mutellina (L.) Crantz, LuzuLuzu - Luzula luzuloides (Lam.) Dandy et Wilmott, LuzuSylv - Luzula sylvatica (Huds.) Gaudin, NardStric - Nardus stricta L., PhytSpic - Phyteuma spicatum L., PoaAnnu - Poa annua L., PoaChaix - Poa chaixii Vill., RanuAcr - Ranunculus acris L., RanuRep - Ranunculus repens L., RumeArif - Rumex arifolius All., SeneHerc - Senecio hercynicus Herborg, StelNemo - Stellaria nemorum L., TaraRud - Taraxacum sect. Taraxacum Kirschner et Štěpánek, TephCris - Tephroseris crispa (Jacq.) Rchb., TrieEur - Trientalis europaea L., VeroCham - Veronica chamaedrys L.

managed. Threatened and endangered plants (Grulich, 2017), that occurred in the surrounding of Švýcárna lodge in the past (citations in Bureš, 2013) were e.g. Anemonastrum narcissiflorum (L.) Holub, Arabidopsis halleri (L.) O'Kane et Al-Shehbaz subsp. halleri, Arnica montana L. subsp. montana, Crepis sibirica L., Epilobium anagallidifolium Lam., Epilobium nutans F.W. Schmidt., Gentiana verna L. subsp. verna, Pilosella flagellaris (Willd.) Arv.-Touv., Pinguicula vulgaris L. subsp. vulgaris, Pseudorchis albida (L.) Á. Löve et D. Löve, Rhinanthus riphaeus Krock., Sagina saginoides (L.) Karsten, Trichophorum alpinum (L.) Pers., Trifolium spadiceum L., Valeriana dioica L.

According to Bureš (2013) there are several reasons for the decrease in species diversity in many localities of Hrubý Jeseník Mts., however some of them are common, e.g.:

a) the end of the grassland management in areas above the tree line; 
b) site's eutrophication through the nitrogen emissions;

c) planting of dwarf-pine, which is considered as an alien species in Hrubý Jeseník Mts.;

d) insufficient nature protection.

As many authors documented (Dullinger et al., 2003; Isselstein et al., 2005; Prévosto et al., 2011), abandonment of semi-natural grasslands from agricultural use is a major risk for grassland diversity. Many investigators have shown that almost independently of the vegetation type, cessation of grassland management leads to a successional change and to a loss of plant species diversity. At a local scale, vegetation succession facilitates the invasion of shrubs, the dominance of tall growing species from later successional stages and the competitive exclusion of species typical for managed grasslands (Krahulec et al., 2001; Moog et al., 2002; Pykälä, 2003; Gaisler et al., 2004; Hejcman et al., 2004; Kryszak and Kryszak, 2005; Zarzycki and Mistral, 2010; Bohner and Starlinger, 2011).

Therefore, positive changes in localities where the renewed grazing was introduced after a longterm of grassland management cessation can be expected regarding the floristic composition and plant species diversity. The effects of grazing on vegetation tend to be explained primarily by visible, above-ground changes in the vegetation and litter structure due to defoliation and trampling (Bokdam and Gleichman, 2000). Animal browsing and trampling causes the creation of open habitats, which enable many plant species to germinate and survive. Grazing also affects the return of nutrients into the soil, which changes chemical soil properties (Krahulec et al., 1996).

As an example of the positive influence of grazing on important biotopes is the study of Lord (1990), who documented that grazing would appear to be necessary for the maintenance of indigenous species in the strongly modified short tussock grassland. The importance of grazing as a tool to maintain grassland biodiversity was emphasized also by Gutser and Kuhn (1998), Kasperczyk and Sczewczyk (1999), Partzsch (2000) or Drozdz (2001).

So far, ecologists have not been able to establish one general, unifying theory for successionally induced changes in a species composition following abandonment. In fact, the course of succession seems to be unique for each site and year (Kahmen and Poschlod, 2004). As Tasser and Tappeiner (2002) explained, succession starts immediately after abandonment. Depending on altitude, succession proceeds at different speeds and with different numbers of stages. Hence, the type of vegetation indicates the time passed after abandonment. According to Hejcman et al. (2002) the typical pasture sward does not recreate itself earlier than 40 years after the renewed grazing introduction. Nevertheless, some positive results can be found also in short-term periods as some current studies indicate.

Our study showed that renewed cattle grazing results in an increase in plant species richness and moreover the occurrence of rare plant species was enhanced. Another example of the successful introduction of renewed grazing of small ruminants can be the experimental pasture of sheep in the National Nature Reserve Mohelno Serpentine Steppe. As Veselý and Řepka (2005) documented, five years after the renewed grazing introduction an increase of plant species diversity was found on monitored plots. A similar approach with positive results was applied also in the Protected Landscape Area Beskydy and in the Protected Landscape Area Bílé Karpaty (Piro and Wolfová, 2008). Traditional ways of grassland management via sheep and cattle grazing are used also in the Krkonoše National Park or in the Louny Central Uplands in the Czech Republic. In the mentioned protected areas, grazing should help to preserve biological diversity, ecological stability and landscape-forming function of semi-natural grasslands.

\section{CONCLUSION}

Concerning the current research conducted in the Protected Landscape Area Jeseníky, the renewed cattle grazing in the surroundings of Švýcárna lodge should not only be the symbolic return to the traditional way of grassland management, but it is primarily the tool to suppress ecological succession (which leads to the overgrowing of biologically valuable habitats) and to enhance species diversity. After six years of restored grazing the overall species richness enhanced and a higher dominance of rare and endangered species was noticed. This could be most likely due to cattle trampling and thus enabling creation of small open habitats for new species germination and survival. The dominance of some common species like Vaccinium myrtillus L. and Calamagrostis villosa (Chaix) Gmel. tended to decrease within a grazing period in favor of a new species colonisation. As Bureš (2013) mentioned, it is not possible to reconstruct the status of subalpine and alpine vegetation in times when grazing utilization culminated. It is, however, important to bear in mind that in a considerable part of the Hrubý Jeseník Mts. the most valuable natural treasures in the forestless enclaves could be conserved. These treasures have to be maintained for following generations by means of an adequate maintenance of such localities. 
Acknowledgements

The work was supported by the institutional support for the long-term conceptual development of the research organisation, Ministry of Agriculture Decision No. R01218 from 26 February 2018 and by the Technology Agency of the Czech Republic, project No. TH02030144. The authors would like to thank the Administration of the Protected Landscape area Jeseníky and the Forests of the Czech Republic, state-owned enterprise for enabling this research in the Praděd National Natural Reserve.

\section{REFERENCES}

BOHNER, A. and STARLINGER, F. 2011. Effects of abandonment of montane grasslands on plant species composition and species richness - a case study in Styria, Austria. Grassland Science in Europe, 16: 604-606.

BOKDAM, J. and GLEICHMAN, J. M. 2000. Effects of grazing by free-ranging cattle on vegetation dynamics in a continental north-west European heathland. Journal of Applied Ecology, 37(3): 415-431.

BRABEC, J., BUCHAROVÁ, A. and ŠTEFÁNEK, M. 2011. Impact of management on the life cycle of Gentianella praecox subsp. Bohemika [in Czech: Vliv obhospodařování na životní cyklus hořečku mnohotvarého českého (Gentianella paecox subsp. Bohemica)] Príroda, 31: 85-109.

BUREŠ, L. 2013. Protected and endangered species of PLA Jeseniky [in Czech: Chráněné a ohrožené rostliny CHKO Jeseníky]. Olomouc: Agentura Rubico.

CHYTRÝ, M., KUČERA, T. and KOČÍ, M. (Eds.). 2010. Habitat catalogue of the Czech Republic [in Czech: Katalog biotopů České republiky]. Praha: Agentura ochrany př́rody a krajiny ČR.

DANIHELKA, J., CHRTEK, J. JR and KAPLAN, Z. 2012. Checklist of vascular plants of the Czech Republic. Preslia, 84(3): 647-811.

DROZDZ, A. 2001. The need to introduce sustainable animal production in the mountains [in Polish: O potrzebie wprowadzenia zasad zrownowazonej produkcji zwierzecej w gorach]. Roczniki Naukowe Zootechniki, 11: 55-63.

DULLINGER, S., DIRNBÖCK, T., GREIMLER, J. and GRABHERR, G. 2003. A resampling approach for evaluating effects of pasture abandonment on subalpine plant species diversity. Journal of Vegetation Science, 14(2): 243-252.

GAISLER, J., HEJCMAN, M. and PAVLÜ, V. 2004. Effect of different mulching and cutting regimes on the vegetation of upland meadow. Plant, Soil and Environment, 50(7): 324-331.

GRULICH, V. 2017. The Red List of vascular plants of the Czech Republic [in Czech: Červený seznam ohrožených druhů české republiky cévnaté rostliny]. Př́roda, 35: 75-132. (in Czech).

GUTSER, D. and KUHN, J. 1998. Sheep and goat grazing of former mowers (hummocky meadows near Mittenwald): effects on vegetation and flora, recommendations on grazing mode [in German: Schaf- und Ziegenbeweidung ehemaliger Mähder (Buckelwisen bei Mittenwald): Auswirkungen auf Vegetation und Flora, Empfehlungen zum Beweidungsmodus]. Zeitschrift für Ökologie und Naturschutz, 7(2): 85-97.

HEJCMAN, M., PAVLÜ, V. and GAISLER, J. 2004. Vegetation structure under unmanaged, grazed and cut grassland in the Giant Mountains, Czech Republic. Grassland Science in Europe, 9: 213-215.

HEJCMAN, M., PAVLŮ, V., HEJCMANOVÁ, P., GAISLER, J., HAKL, J. and RAUCH, O. 2006. Farmer decision making and its effect on the subalpine grassland succession in the Giant Mts., Czech Republic. Acta Societatis Botanicorum Poloniae, 75(2): 165-174.

HEJCMAN, M., PAVLÜ, V. and KRAHULEC, F. 2002. Livestock grazing and its use in conservation practice [in Czech: Pastva hospodářských zvírat a její využití v ochranářské praxi]. Zprávy České botanické společnosti, 37(2): 203-216.

HELLSTRÖM, K., HUHTA, A. P., RAUTIO, P., TUOMI, J., OKSANEN, J. and LAINE, K. 2003. Use of sheep grazing in the restoration of semi-natural meadows in northern Finland. Applied Vegetation Science, 6(1): 45-52.

HOFHANZLOVÁ, E. 2006. Gentiana pannonica - an alpine native symbol of the Šumava mountains [in Czech: Hořec panonský - alpský rodák symbolem Šumavy]. Živa, 54: 155-157.

ISSELSTEIN, J., JEANGROS, B. and PAVLŮ, V. 2005. Agronomic aspects of biodiversity targeted management of temperate grasslands in Europe - A review. Agronomy Research, 3(2): 139-151.

KAHMEN, S. and POSCHLOD, P. 2004. Plant functional trait responses to grassland succession over 25 years. Journal of Vegetation Science, 15(1): 21-32.

KASPERCZYK, M. and SCZEWCZYK, W. 1999. Floristic composition of mountain swamps after cessation of use [in Polish: Sklad florystyczny runi gorskich uzytkow zielonych po zaprzestaniu uzytkowania]. Folia Universitatis Agriculturae Stetinensis. Agricultura, 75: 163-165. 
KOLENATI, F. 1860. The high altitude flora of the Praděd locality [in German: Die Hohenfora des Alvaters]. Brünn: Rudolf Rohrer.

KRAHULEC, F., BLAŽKOVÁ, D., BALÁTOVÁ-TULÁČKOVÁ, E., ŠTURSA, J., PECHÁČKOVÁ, S. and FABŠČIČOVÁ, M. 1996. Giant Mountains meadows: plant communities and their dynamics [in Czech: Louky Krkonoš: Rostlinná společenstva a jejich dynamika]. Opera Corcontica, 33: 3-250.

KRAHULEC, F., SKÁLOVÁ, H., HERBEN, T., HADINCOVÁ, V., WILDOVÁ, R. and PECHÁČKOVÁ, S. 2001. Vegetation changes following sheep grazing in abandoned mountain meadows. Applied Vegetation Science, 4(1): 97-102.

KRYSZAK, J. and KRYSZAK, A. 2005. Floristic changes in meadow swards after suspension of utilisation. Grassland Science in Europe, 10: 272-275.

LORD, J. M. 1990. The maintenance of Poa cita grassland by grazing. New Zealand Journal of Ecology, 13: 43-49.

MERUNKOVÁ, K. and CHYTRÝ, M. 2012. Environmental control of species richness and composition in upland grasslands of the southern Czech Republic. Plant Ecology, 213(4): 591-602.

METERA, E., SAKOWSKI, T., SŁONIEWSKI, K. and ROMANOWICZ, B. 2010. Grazing as a tool to maintain biodiversity of grassland - a review. Animal Science Papers and Reports, 28: 315-334.

MLÁDEK, J. 2008. Monitoring of the impact of various management interventions on permanent grassland. In: PIRO, Z. and WOLFOVÁ, J. (Eds.). Conservation of the Carpathian grassland diversity [in Czech: Zachování biodiverzity karpatských luk]. Praha: FOA - Nadační fond pro ekologické zemědělství, pp. 33-36.

MLÁDEK, J., PAVLŮ, V., HEJCMAN, M. and GAISLER, J. 2006. Grazing as a means of maintaining permanent grassland in protected areas. Praha: VÚRV.

MOOG, D., POSCHLOD, P., KAHMEN, S. and SCHREIBER, K. F. 2002. Comparison of species composition between different grassland management treatments after 25 years. Applied Vegetation Science, 5(1): 99-106.

MORAVEC, J. (Ed.). 1994. Phytocoenology [in Czech: Fytocenologie]. Praha: Academia.

PARTZSCH, M. 2000. The porphyry landscape of the lower Saale valley - structural change of its vegetation in the last four decades [in German: Die Porphyrkuppenlandschaft des unteren Saaletals -Strukturwandel ihrer Vegetation in den letzten vier Jahrzehnten]. Tuexenia, 20: 153-187.

PAVLÜ, V., HEJCMAN, M., PAVLÜ, L. and GAISLER, J. 2007. Restoration of grazing management and its effect on vegetation in an upland grassland. Applied Vegetation Science, 10(3): 375-382.

PIRO, Z. and WOLFOVÁ, J. (Eds.). 2008. Preserving biodiversity of the Carpathian meadows [in Czech: Zachování biodiverzity karpatských luk]. Praha: FOA - Nadační fond pro ekologické zemědělství.

PYKÄLÄ, J. 2003. Effects of restoration with cattle grazing on plant species composition and richness of semi-natural grasslands. Biodiversity and Conservation, 12(11): 2211-2226.

PRÉVOSTO, B., KUITERS, L., BERNHARDT-RÖMERMANN, M., DÖLLE, M., SCHMIDT, W., HOFFMANN, M., VAN UYTVANCK, J., BOHNER, A., KREINER, D., STADLER, J., KLOTZ, S. and BRANDL, R. 2011. Impacts of land abandonment on vegetation: successional pathways in European habitats. Folia Geobotanica, 46(4): 303-325.

ŠTENCL, R. 2012. Renewed cattle grazing at Švýcárna [in Czech: Znovuobnovená pastva skotu na Švýcárně]. Ochrana př́rody, 67: 33-33.

TASSER, E. and TAPPEINER, U. 2002. Impact of land use changes on mountain vegetation. Applied Vegetation Science, 5(2): 173-184.

TER BRAAK, C. J. F. and ŠMILAUER, P. 2002. CANOCO Reference Manual and CanoDraw for Windows User's Guide: Software for Canonical Community Ordination (version 4.5). Ithaca: Microcomputer Power.

VESELÝ, P. 2000. Grazing in NNR Mohelno Serpentine Steppe [in Czech: Pastva v NPR Mohelenská hadcová step]. Ochrana prírody, 55(6): 68-170.

VESELÝ, P. and ŘEPKA, R. 2005. Specification of vegetation evaluation after 5 years sheep grazing in NNR Mohelno Serpentine Steppe. In: Proc. of VI Kábrt's Dietetic Days. University of Veterinary and Pharmaceutical Sciences in Brno, pp. 58-61.

ZARZYCKI, J. and MISTRAL, A. 2010. Abandonment of farming practices: impact on vegetation. Grassland Science in Europe, 15: 133-135.

ŽÁKOVÁ, I., BÍLEK, M. and BENDOVÁ, P. 2004. Evaluation of changes in the floristic composition of specially protected Prague areas after 3 years of mixed sheep and goat grazing. In: Proceedings of international scientific conference Pasture and animal. AF MZLU, Brno, pp. 168-177. 